Journal of Luminescence 21 (1980) 165-168

(c) North-Holland Publishing Company

\title{
ON THE LUMINESCENCE OF BISMUTH ALUMINATE $\left(\mathrm{Bi}_{2} \mathrm{Al}_{4} \mathrm{O}_{9}\right)$
}

\author{
G. BLASSE and O Boen Ho \\ Physical Laboratory, State University, PO Box 80.000, 3508 TA Utrecht, \\ The Netherlands
}

Received 5 July 1979

The luminescence of $\mathrm{Eu}^{3+}$ and $\mathrm{Tb}^{3+}$ in $\mathrm{Bi}_{2} \mathrm{Al}_{4} \mathrm{O}_{9}$ is reported. It is shown that the $\mathrm{Bi}^{3+}$ excitation energy does not migrate through the lattice. The $\mathrm{Cr}^{3+}$ ion shows $704.5 \mathrm{~nm}$ line emission in this host lattice.

\section{Introduction}

Bismuth aluminate, $\mathrm{Bi}_{2} \mathrm{Al}_{4} \mathrm{O}_{9}$, has recently been reported to show efficient, green luminescence at room temperature [1]. The isomorphous compound $\mathrm{Bi}_{2} \mathrm{Ga}_{4} \mathrm{O}_{9}$ did not luminescence. Luminescence at room temperature is a rare phenomenon for bismuth compounds. Other examples are $\mathrm{Bi}_{4} \mathrm{Si}_{3} \mathrm{O}_{12}$ [2] and $\mathrm{Bi}_{4} \mathrm{Ge}_{3} \mathrm{O}_{12}$ [3].

The crystal structure of $\mathrm{Bi}_{2} \mathrm{Al}_{4} \mathrm{O}_{9}$ is known [4]. The $\mathrm{Al}^{3+}$ ions are in equal amounts in tetrahedral and octahedral coordination. The $\mathrm{Bi}^{3+}$ ion has only three near oxygen neighbours at one side.

Since the shortest $\mathrm{Bi}-\mathrm{Bi}$ distance amounts to only $4 \AA$, energy migration through the host lattice is easy conceivable. We tried to study this by using rare earth ions as trap centres. Further it seemed tempting to investigate the reasons why $\mathrm{Bi}_{2} \mathrm{Ga}_{4} \mathrm{O}_{9}$ does not luminesce at room temperature.

\section{Experimental}

Samples were prepared as described in ref. [1]. All products were fluxed with $\mathrm{NaCl}$. After washing the products were shown to be single-phase by X-ray analysis. The performance of the optical measurements has been described before [5].

\section{Results}

Our samples $\mathrm{Bi}_{2} \mathrm{Al}_{4} \mathrm{O}_{9}$ show the same luminescence characteristics as described before [1]: a broad emission band peaking at $490 \mathrm{~nm}$ and a broad excitation band 
peaking at $285 \mathrm{~nm}$. The position of these bands is practically temperature independent down to liquid helium temperature. We tried to dope this compound with $\mathrm{Tb}^{3+}$ and $\mathrm{Eu}^{3+}$ in concentrations up to one atomic per cent. In the doped samples the rare earth emission could be directly excited in the characteristic rare earth bands. If excitation was into the host lattice, this emission could hardly be detected on the broad host lattice emission band. This was independent of temperature up to $300 \mathrm{~K}$. We conclude that the excitation energy does not migrate through the lattice.

All aluminate samples showed in addition a red emission band peaking at about $700 \mathrm{~nm}$ with a corresponding excitation band with a maximum at $380 \mathrm{~nm}$. This emission is absent at room temperature, but is present at liquid nitrogen temperature. We assume that it is due to an impurity. This might be, for example, $\mathrm{Fe}^{3+}[6]$, although the value of the decay time is too short (see below). Another possibility is the presence of a small amount of a second phase of the sillenite type [7,8]. Compounds of this type (like $\mathrm{Bi}_{12} \mathrm{SiO}_{20}$ and $\mathrm{Bi}_{12} \mathrm{GeO}_{20}$ ) are known to luminesce [9] and have optical properties that are very similar to the ones we observed. This additional emission will not be discussed further.

The $\mathrm{Bi}_{2} \mathrm{Ga}_{4} \mathrm{O}_{9}$ sample showed luminescence below room temperature. The results are comparable with those for $\mathrm{Bi}_{2} \mathrm{Al}_{4} \mathrm{O}_{9}$. The maxima of the emission and
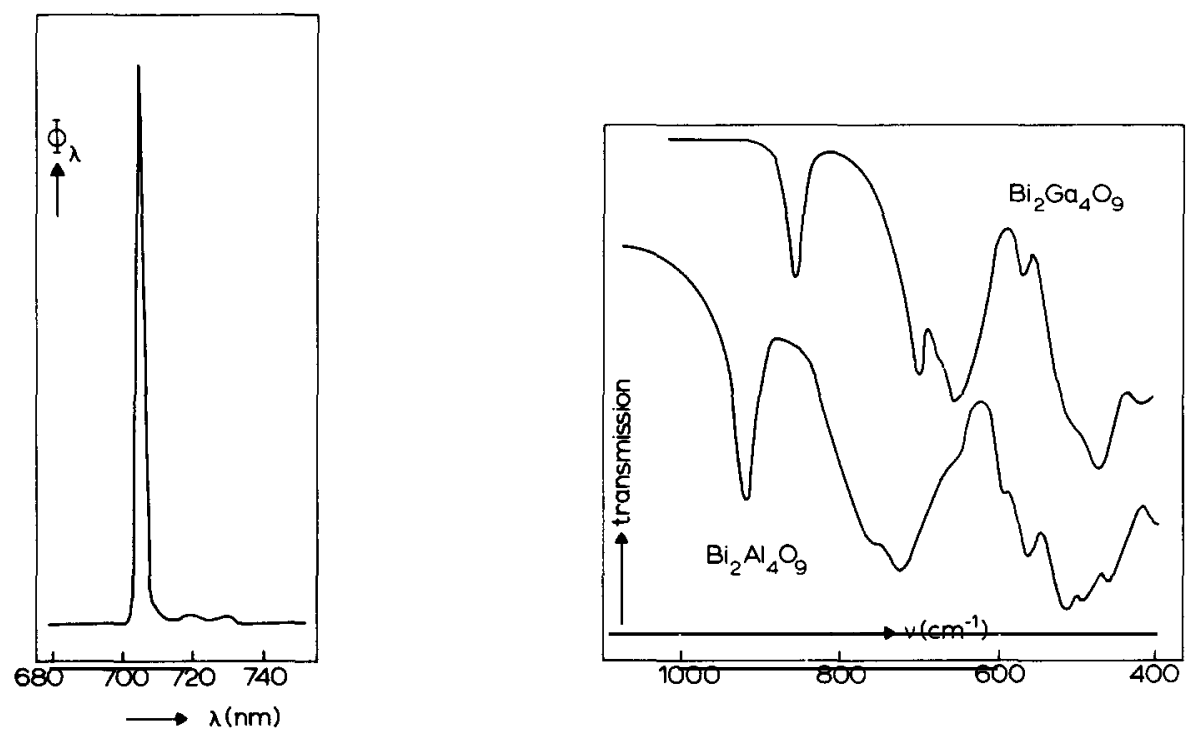

Fig. 1. Spectral energy distribution of the $\mathrm{Cr}^{3+}$ emission of $\mathrm{Bi}_{2} \mathrm{Al}_{4} \mathrm{O}_{9}: \mathrm{Cr}^{3+}$ at liquid helium temperature under host lattice excitation. $\Phi_{\lambda}$ presents the spectral radiant power per unit wavelength interval in arbitrary units.

Fig. 2. Infrared spectra of $\mathrm{Bi}_{2} \mathrm{Al}_{4} \mathrm{O}_{9}$ and $\mathrm{Bi}_{2} \mathrm{Ga}_{4} \mathrm{O}_{9}$ at room temperature. 
excitation band are 530 and $285 \mathrm{~nm}$, respectively (values at liquid nitrogen temperature).

The $\mathrm{Cr}^{3+}$ ion changes the luminescence behavior of $\mathrm{Bi}_{2} \mathrm{Al}_{4} \mathrm{O}_{9}$ more drastically than the rare earth ions. For a $\mathrm{Cr}^{3+}$ concentration of 0.5 at.\% about $30 \%$ of the emission originates from the $\mathrm{Cr}^{3+}$ ion and $70 \%$ from the host lattice itself (values at $4.2 \mathrm{~K}$ under host lattice excitation). $\mathrm{The}^{\mathrm{Cr}^{3+}}$ emission at this temperature consists of a narrow emission line peaking at $704.5 \mathrm{~nm}$ followed by some weak vibronic features at about 300 and $500 \mathrm{~cm}^{-1}$ (fig. 1).

The infrared spectra down to $400 \mathrm{~cm}^{-1}$ are presented in fig. 2 ( $\mathrm{KBr}$-pellets). The bands at $910 \mathrm{~cm}^{-1}$ and about $750 \mathrm{~cm}^{-1}$ in the case of the aluminate are at much higher frequencies than the corresponding beands in the case of the gallate indicating that they have mainly $\mathrm{Al}-\mathrm{O}$ character. In the $500 \mathrm{~cm}^{-1}$ region the differences are less outspoken indicating a certain $\mathrm{Bi}-\mathrm{O}$ character.

Finally we performed decay time measurements on the $\mathrm{Bi}_{2} \mathrm{Al}_{4} \mathrm{O}_{9}$ sample. The $490 \mathrm{~nm}$ emission band has at $10 \mathrm{~K}$ a decay time of $14 \mu \mathrm{s}$. The value decreases slowly to $4 \mu \mathrm{s}$ at $100 \mathrm{~K}$. The corresponding values for the red, additional emission are 26 $\mu \mathrm{s}$ and $4 \mu \mathrm{s}$.

\section{Discussion}

The luminescence of the $\mathrm{Bi}^{3+}$ ion is well known and reasonably understood $[10,11]$. The emission is ascribed to the ${ }^{3} \mathrm{P}_{1}-{ }^{1} \mathrm{~S}_{0}$ transition. Below the emitting ${ }^{3} \mathrm{P}_{1}$ level the ${ }^{3} \mathrm{P}_{0}$ level is acting as an optical trap [11]. Following Brixner [1] we ascribe the excitation band of $\mathrm{Bi}_{2} \mathrm{Al}_{4} \mathrm{O}_{9}$ to the ${ }^{1} \mathrm{~S}_{0}-{ }^{3} \mathrm{P}_{1}$ transition on the $\mathrm{Bi}^{3+}$ ion. The emission at room temperature is due to the ${ }^{3} \mathrm{P}_{1} \rightarrow{ }^{1} \mathrm{~S}_{0}$ transition. From the short decay time at low temperature we have to conclude that even at these temperatures the emission is still mainly from the ${ }^{3} \mathrm{P}_{1}$ level, since the radiative decay time from ${ }^{3} \mathrm{P}_{0}$ amounts to several hundreds of microseconds. This points to a very small energy difference between the ${ }^{3} \mathrm{P}_{0}$ and ${ }^{3} \mathrm{P}_{1}$ level as has been discussed elsewhere [12].

The Stokes shift of the $\mathrm{Bi}^{3+}$ emission in $\mathrm{Bi}_{2} \mathrm{Al}_{4} \mathrm{O}_{9}$ amounts to $15000 \mathrm{~cm}^{-1}$ which is large [12]. As a consequence the luminescent centre relaxes considerably after excitation. As a consequence the energy migration between $\mathrm{Bi}^{3+}$ ions mutually has a large thermal activation energy $[13,14]$. Since the $\mathrm{Bi}^{3+}$ excitation energy is not transferred to rare earth ions in the lattice, we conclude that even at room temperature the relaxation cannot be counteracted by thermal activation and that the excitation energy does not migrate through the host lattice. As a consequence no concentration quenching occurs and $\mathrm{Bi}_{2} \mathrm{Al}_{4} \mathrm{O}_{9}$ emits at room temperature in spite of its high $\mathrm{Bi}^{3+}$ concentration.

The Stokes shift in the case of $\mathrm{Bi}_{2} \mathrm{Ga}_{4} \mathrm{O}_{9}$ is still larger, viz. $16500 \mathrm{~cm}^{-1}$. This makes energy migration even more improbable, so that the lower quenching temperature of the luminescence of $\mathrm{Bi}_{2} \mathrm{Ga}_{4} \mathrm{O}_{9}$ in comparison with that of $\mathrm{Bi}_{2} \mathrm{Al}_{4} \mathrm{O}_{9}$ 
is due to the larger offset of the excited state parabola in the case of the gallate.

Let us finally consider the results for $\mathrm{Bi}_{2} \mathrm{Al}_{4} \mathrm{O}_{9}: \mathrm{Cr}^{3+}$. Since the $\mathrm{Bi}^{3+}$ excitation energy is not mobile, the energy transfer mechanism between the $\mathrm{Bi}^{3+}$ and $\mathrm{Cr}^{3+}$ ions consists of a one-step energy transfer process. From the ratio of the $\mathrm{Bi}^{3+}$ and the $\mathrm{Cr}^{3+}$ emission intensity and the cell parameters of $\mathrm{Bi}_{2} \mathrm{Al}_{4} \mathrm{O}_{9}$ [4], the critical distance for this transfer is estimated to be $9 \AA$ at liquid helium temperature. The ${ }^{3} \mathrm{P}_{1}-{ }^{1} \mathrm{~S}_{0}$ emission of the $\mathrm{Bi}^{3+}$ ion overlaps mainly with the ${ }^{4} \mathrm{~A}_{2} \rightarrow{ }^{4} \mathrm{~T}_{1}(\mathrm{~F})$ absorption band of the $\mathrm{Cr}^{3+}$ ion. In view of the reaonable absorption strength of both transitions the value of $9 \AA$ is not unreasonable for energy transfer by electric dipole interaction.

The emission of the $\mathrm{Cr}^{3+}$ ion at $704.5 \mathrm{~nm}$ originates from the ${ }^{2} \mathrm{E}$ level in view of its sharp line character [15]. The ${ }^{2} \mathrm{E}$ level is, therefore, situated below the ${ }^{4} \mathrm{~T}_{2}$ level. The maximum of the ${ }^{4} \mathrm{~A}_{2} \rightarrow{ }^{4} \mathrm{~T}_{2}$ absorption band is in fact found at much higher energies, viz. at $620 \mathrm{~nm}$. The vibronic features at 300 and $500 \mathrm{~cm}^{-1}$ are ascribed to coupling with vibrations which have mainly $\mathrm{Bi}-\mathrm{O}$ character (see above).

In the near future we hope to perform measurements at very low temperatures on the undoped bismuth compounds.

\section{References}

[1] L.H. Brixner, Mat. Res. Bull. 13 (1978) 563.

[2] G. Blasse, Philips Res. Repts. 23 (1968) 344.

[3] M.J. Weber and R.R. Monchamp, J. App. Phys. 44 (1973) 5495.

[4] N. Niizeki and M. Wachi, Z. Kristallogr. 127 (1968) 173;

R. Arpe and Hk. Müller-Buschbaum, J. Inorg. Nucl. Chem. 39 (1977) 233.

[5] H. Ronde and G. Blasse, J. Inorg. Nucl. Chem. 40 (1978) 215.

[6] N.T. Melamed, P.J. Viccaro, J.O. Artman and F. de S. Barros, J. Luminescence 1/2 (1970) 348.

[7] E.M. Levin and R.S. Roth, J. Res. Natl. Bur. Std. 68A (1964) 197.

[8] S.C. Abrahams, P.B. Jamieson and J.L. Bernstein, J. Chem. Phys. 47 (1967) 4034.

[9] R.B. Lauer, Appl. Phys. Lett. 17 (1970) 178.

[10] G. Blasse and A. Bril, J. Chem. Phys. 48 (1968) 217.

[11] G. Boulon, J. de Phys. 32 (1971) 333;

G. Boulon, C. Pédrini, M. Guidoni and Ch. Pannel, J. de Phys. 36 (1975) 267.

[12] G. Blasse and A.C. van der Steen, Solid States Commun. 31 (1979) 993.

[13] W.H. Fonger and C.W. Struck, J. Luminescence 17 (1978) 241.

[14] C. Hsu and R.C. Powell, J. Luminescence 10 (1975) 273.

[15] G.F. Imbusch, in: Luminescence of Inorganic Solids, ed. B. di Bartolo (Plenum Press, New York, 1978) p. 115. 